Int. J. Electrochem. Sci., 15 (2020) $1022-1033$

International Journal of

ELECTROCHEMICAL

SCIENCE

$\underline{\text { www.electrochemsci.org }}$

\title{
Treatment of Aged Landfill Leachate by a Self-Sustained Microbial Fuel Cell-Microbial Electrolysis Cell System
}

\author{
Qi Feng ${ }^{1}$, Longjun $\mathrm{Xu}^{1, *}$, Yanzhao $\mathrm{X} \mathrm{u}^{1,2}$, Chenglun Liu ${ }^{1,3}$, Yuan $\mathrm{Lu}^{1}$, Hailong Wang ${ }^{1}$, \\ Tingzeng $W^{l}$, Ruiqi Wang ${ }^{l}$, Yan Chen ${ }^{l}$, Yong Cheng ${ }^{l}$ \\ ${ }^{1}$ State Key Laboratory of Coal Mine Disaster Dynamics and Control, Chongqing University, \\ Chongqing 400044, China \\ ${ }^{2}$ Chengdu Aircraft Industrial (Group) Co., Ltd, Cheng du 610073, China \\ ${ }^{3}$ College of Chemistry and Chemical Engineering, Chongqing University, Chongqing 400044, China \\ *E-mail: xulj@cqu.edu.cn
}

doi: $10.20964 / 2020.01 .19$

Received: 1 August 2019 / Accepted: 24 October 2019 / Published: 30 November 2019

Microbial fuel cells (MFCs) can supply power and drive reactions for microbial electrolysis cells (MECs) when they are connected in series. This study designed three different air-cathode singlechamber MFC-MEC systems constructed with aged landfill leachate as the substrate to enhance energy recovery and pollutant removal efficiency. These systems were designated as MFC $\left(\mathrm{S}_{1}\right), \operatorname{MFC}-\mathrm{MEC}\left(\mathrm{S}_{2}\right)$ and MFC-MEC-MFC $\left(\mathrm{S}_{3}\right)$. Maximum voltage outputs of 146, 421, and $253 \mathrm{mV}$ were obtained from the $S_{1}, S_{2}$ and $S_{3}$ systems, respectively. The removal efficiency of COD in the $S_{2}$ and $S_{3}$ systems was significantly enhanced compared to that of the $S_{1}$ system, and the removal rate of ammonia could reach more than $90 \%$. In addition, the degradation of ammonia nitrogen in the $S_{1}$ and $S_{2}$ systems was consistent with fractal reaction kinetics, providing a theoretical basis for pollutant removal in the future. Therefore, it was demonstrated that the associated system could enhance the performance of electricity generation and thus could be applied to enrich wastewater treatment efficiency as a new and promising approach.

Keywords: microbial fuel cell; microbial electrolysis cell; landfill leachate; chemical oxygen demand; ammonia

\section{$\underline{\text { FULL TEXT }}$}

(C) 2020 The Authors. Published by ESG (www.electrochemsci.org). This article is an open access article distributed under the terms and conditions of the Creative Commons Attribution license (http://creativecommons.org/licenses/by/4.0/). 